\title{
IMPLEMENTASI KETELADANAN PEMIMPIN ROHANI BERDASARKAN FILIPI 2: 1-8 BAGI GEMBALA GEREJA PENTAKOSTA DI PAPUA KLASIS MIMIKA
}

\author{
Fransiscus Xaferius Wanggai ${ }^{1 *}$, Sutikto ${ }^{2}$, Roberth Ruland Marini ${ }^{3}$ \\ Sekolah Tinggi Alkitab Jember ${ }^{123}$ \\ *)Email Correspondence: stajember@ rocketmail.com
}

\begin{abstract}
The main problem in this research is the example of spiritual leaders when shepherding the congregation. Some of the factors that make the pastor not an example are: repentance, character and minimal human resources. This study applies a qualitative method. The researcher uses the Bible as the main source, also uses literature from several sources of books and journals, to get a clear picture of the example of spiritual leaders based on Philippians 2:1-8, which will later be implemented in the leadership of the pastoral congregation of the Pentecostal Church in Tanah Papua (GPDP). Special Mimika Classics. The results of the study show that in Christian leadership, the pastor as the leader of the local congregation can influence the people he leads. Philippians 2:1-8 is Paul's writing that teaches about the example of Jesus Christ as a spiritual leader, which can be seen from principles, ministry, and personality.
\end{abstract}

Keywords: $\quad$ Philippians 2, Example, Spiritual Leader.

Abstraksi: Permasalahan utama dalam penelitian ini adalah keteladanan pemimpin rohani pada waktu menggembalakan jemaat. Beberapa faktor yang membuat gembala sidang tidak menjadi teladan yaitu: pertobatan, karakter dan sumber daya manusia yang minim. Penelitian ini menerapkan metode kualitatif. Peneliti menggunakan Alkitab sebagai sumber utama, juga menggunakan literatur dari beberapa sumber buku dan jurnal, untuk mendapatkan gambaran yang jelas tentang keteladalan pemimpin rohani berdasarkan Filipi 2: 1-8, yang nantinya diimplementasikan dalam kepemimpian gembala sidang Gereja Pentakosta Di Tanah Papua (GPDP) secara khusus Klasis Mimika. Hasil penelitian menunjukkan dalam kepemimpinan Kristen, gembala sebagai pemimpin jemaat lokal dapat memengaruhi orang yang dipimpinnya. Surat Filipi 2: 1-8 adalah tulisan Paulus yang mengajarkan tentang keteladanan Yesus Kristus sebagai pemimpin rohani, yang dapat dilihat dari prinsip, pelayanan dan kepribadian.

Kata kunci: Filipi 2, Keteladanan, Pemimpin Rohani.

\section{PENDAHULUAN}

Kepemimpinan adalah suatu kegiatan untuk memengaruhi orang lain supaya melakukan apa yang menjadi perintahnya. ${ }^{1}$ Kepemimpinan selain dapat memengaruhi tindakan atau perbuatan orang lain, juga dapat memengaruhi

1 John. C. Maxwell, Mengembangkan kepemimpinan di dalam diri anda (Tangerang: Binarupa Aksara, 2010), 1. 
perubahan karakter orang-orang yang dipimpinnya. Demikian pula halnya dengan kepemimpinan Kristen sebagai pemimpin dalam jemaat lokal atau dalam organisasi gereja dapat memengaruhi orang yang dipimpin. Gembala sidang adalah seorang pemimpin rohani dalam jemaat dan juga disebut pemelihara domba. Perannya Gembala dalam jemaat atau organisasi gereja sangat vital dan strategis, karena menjadi orang yang bertanggung jawab terhadap visi dan misi dari gereja atau organisasi yang dipimpin.

Leroy Eims mengatakan, keberhasilan atau kegagalan organisasi adalah tanggung jawab seorang pemimpin. ${ }^{2}$ Kepemimpinan bukan berdasarkan tingginya jabatan dan besarnya organisasi yang dipimpin, tetapi bagaimana pengaruhnya bagi orang-orang yang dipimpin dan relasi yang berkualitas dengan semua orang di sekitarnya. ${ }^{3}$ Pemimpin perlu menciptakan keteraturan dan kenyamaman untuk orang-orang yang dipimpinnya. ${ }^{4}$ Seorang pemimpin bukan hanya mampu memimpin, tetapi perlu menjadi contoh atau teladan dalam kehidupan. ${ }^{5}$ Kepemimpinan Yesus adalah teladan bagi gembala masa kini. ${ }^{6}$ Beberapa teladan kepemimpinan Yesus dalam kitab Injil yaitu: karakter, kerohanian, manajemen dan pelayanan. ${ }^{7}$ Pemimpin Kristen perlu memiliki

2 Leroy Eims, 12 ciri kepemimpinan yang efektif (Bandung: Kalam Hidup, 2003), 12.

3 Firman Panjaitan, "Kepemimpinan Yesus Kristus sebagai Model Dasar Kepemimpinan Kristen Berdasarkan Matius 20: 20-28," KINAA: Jurnal Kepemimpinan Kristen dan Pemberdayaan Jemaat 1, no. 2 (2020): 91, https://doi.org/10.34307/kinaa.v1i2.14.

${ }^{4}$ Martje Panekenan, "Pola Kepemimpinan Kristen Menurut Injil Yohanes 13: 1-20," Educatio Christi 1, no. 1 (2020): 41, https://ejournal.teologi-ukit.ac.id/index.php/educatio-christi/article/view/9/6.

5 Desti Samarenna dan Harls Evan R Siahaan, "Memahami Dan Menerapkan Prinsip Kepemimpinan Orang Muda Menurut 1 Timotius 4: 12 Bagi Mahasiswa Teologi," BIA': Jurnal Teologi dan Pendidikan Kristen Kontekstual 2, no. 1 (2019): 1, https://doi.org/10.34307/b.v2i1.60.

${ }^{6}$ Agus Purwanto, "Kepemimpinan Yesus Kristus sebagai Model Kepemimpinan Kristen," Mathetes: Jurnal Teologi dan Pendidikan Kristen 1, no. 2 (2020): 131, https://sttbethelsamarinda.ac.id/ejournal/index.php/mathetes/article/view/17.

7 K Katarina dan I Putu Ayub Darmawan, "Alkitab dalam Formasi Rohani pada Era Reformasi Gereja dan Implikasi bagi Gereja Pada Masa Kini," EPIGRAPHE: Jurnal Teologi dan Pelayanan Kristiani 3, no. 2 (18 Desember 2019): 87, https://doi.org/10.33991/epigraphe.v3i2.85. 
karakter yang baik, rendah hati, berbelaskasihan dan dapat dipercaya. ${ }^{8}$ Dalam Filipi 2: 1-8 Paulus memberikan nasihat agar belajar dari teladan Yesus Kristus sebagai pemimpin. Yesus menunjukkan model kepemimpian yang unggul dan dapat dijadikan teladan oleh para pemimpin rohani. ${ }^{9}$

Harapan dari gereja dalam bentuk organisasi adalah mencapai suatu keberhasilan, salah satu faktor keberhasilan disebabkan oleh fungsi pemimpin pastoral. ${ }^{10}$ Berdasarkan data dari Pengurus Sinode Gereja Pentakosta di Tanah Papua (GPDP) kalsis Mimika, dari sembilan gembala sidang ada beberapa gembala yang mendapat surat teguran tindakan disiplin organisasi. Pertama, surat teguran bagi satu orang yang melakukan perbuatan asusila dengan jemaat. Kedua, surat teguran bagi empat orang yang tidak menyetor persepuluhan jemaat ke sinode. Karena kurang memahami peraturan organisasi serta ada unsur kesengajaan untuk melanggar. Ketiga, surat pemecatan bagi tiga orang yang berusaha mengajak gembala lain untuk mendirikan sinode baru. Hal tersebut menunjukkan jika gembala sidang memimpin demikian maka tujuan dari sebuah gereja secara organisasi tidak terwujud, stagnan dan keteladanan tidak mampu diterapkan di antara pemimpin rohani. Selanjutnya, terkait dari dasar pemikiran di atas, khususnya pada GPDP klasis Mimika, Papua, berdasarkan data dari Pengurus Sinode GPDP kalsis Mimika terdapat problematika bebrepa pemimpin gembala sidang. ${ }^{11}$ Berdasarkan latar belakang masalah tersebut, maka penting

8 Sayang Tarigan dan Yanto Paulus Hermanto, "Kepemimpinan Tuhan Yesus di Masa Krisis Sebagai Model Kepemimpinan Kristen Saat Ini," HARVESTER: Jurnal Teologi dan Kepemimpinan Kristen 6, no. 1 (2021): 38, https://doi.org/10.52104/harvester.v6i1.54.

9 Bimo Setyo Utomo, "Karakteristik Kepemimpinan Hamba Yesus Kristus Menurut Filipi 2: 5-8," DIEGESIS: Jurnal Teologi Kharismatika 3, no. 2 (2020): 107, https://doi.org/10.53547/diegesis.v3i2.78.

10 Yosafat B, Integritas Pemimpin Pastoral (Yogyakarta: ANDI, 2010), 11.

11 pertama, keberadaan GPDP Klasis Mimika sudah cukup lama sejak tahun 1997 dan tingkat pertumbuhan serta kemajuan jemaat cukup signifikan hingga saat ini berjumlah sembilan jemaat, yaitu: Jemaat Siryon 200 jiwa, Jemaat Siloam 300 jiwa, Jemaat Air Hidup 200 jiwa, Jemaat Semua Umat 250 jiwa, 
untuk merumuskan penelitian tetang implementasi keteladanan pemimpin rohani berdasarkan Filipi 2: 1-8 bagi gembala sidang GPDP Klasis Mimika Papua.

\section{METODE}

Penelitian ini menerapkan metode kualitatif, wawancara dilakukan sebagai dasar mengetahui problematika. Selanjutnya penelitian ini menerapkan studi literatur, Alkitab sebagai sumber utama didukung oleh literartur dari buku dan jurnal, untuk mendapatkan deskripsi tentang keteladalan pemimpin rohani menurut Filipi 2: 1-8, yang diimplementasikan bagi gembala sidang GPDP klasis Mimika. Partisipan dalam penelitian ini adalah sembilan orang gembala sidang GPDP klasis Mimika. Untuk mencapai tujuan penelitian, maka data dikumpulkan melalui wawancara terstruktur dengan pedoman wawancara dalam bentuk pertanyaan terbuka. Selanjutnya data dianalisis melalui studi induktif dan diuraikan dalam bentuk narasi.

\section{HASIL}

Berdasarkan hasil observasi dan wawancara terstruktur tentang keteladan pemimpin rohani menurut Filipi 2: 1-8 pada sembilan partisipan maka diperoleh hasil sebagai berikut. Pertama, keteladanan dalam kepribadian. Pertanyaan kepada sembilan partisipan: bila ditinjau dari Filipi 2:1-8, apakah teladan pelayanan dari gembala sidang sebagai pemimpin rohani? Jawaban mereka dapat

\footnotetext{
Jemaat Eden 200 jiwa, Jemaat Sion 350 jiwa, Jemaat Iwaka SP 5250 jiwa, Jemaat Efesus 450 jiwa, Jemaat SP 9300 jiwa. Jadi seluruhnya ada 2500 umat GPDP. Kedua, dari sembilan gembala sidang ada yang berselisih paham, sakit hati dan dendam sekalipun sudah didamaikan. Ketiga, ada gembala sidang yang melanggar aturan-aturan organisasi. Keempat, belum adanya kekompakan di kalangan gembala-gembala GPDP klasis Mimika (Lih.Ketua Sinode, Kondisi Jemaat dan Kepemimpinan Gembala Sidang di GPDP Klasis Mimika, Papua, diwawancara oleh Fransiscus Xaferius Wanggai, Sutikto, dan Roberth Ruland Marini Marini, Wawancara, 2021.).
} 
dirangkum sebagai berikut: kerjasama dalam hal saling membantu, menjaga persatuan, mendukung dan membantu yang sedang kesusahan, rasa persaudaraan sesame rekan kerja, aksi pengumpulan dana dalam setiap pertemuan wilayah, sepenuh hati dan waktu untuk Tuhan. Kedua, keteladanan dalam prinsip. Pertanyaan kepada sembilan partisipan: bila ditinjau dari Filipi 2:1-8, apakah teladan pemimpin rohani dalam hubungannya sesama? Jawaban mereka dapat dirangkum sebagai berikut: pemimpin yang berjiwa peduli, mengerti dan suka menolong, rendah hati, lemah lembut, sopan dan bersahaja, sepikir, bijaksana, menghargai orang yang dipimpin, bertintegritas, berwibawa, focus pada tujuan, memiliki karakter Kristus, bertanggung jawab, siap sedia melayani dan bukan dilayani. Ketiga, keteladanan dalam pelayanan. Pertanyaan kepada sembilan partisipan: bila ditinjau dari Filipi 2:1-8, apakah teladan kepribadian dari gembala sidang sebagai pemimpin rohani? Jawaban mereka dapat dirangkum sebagai berikut: suka berbagi kasih, lembut, tegas dan memiliki hati Bapa, rendah hati, sabar, penuh kasih, mejadi panutan, mengampuni, berkorban dan peduli dengan orang lain, dapat bekerjasama dengan siapa saja, saling menghormati dan menghargai, rajin dan aktif dalam pekerjaan Tuhan, semangat dan keja keras serta kejujuran. $^{12}$

Penelitian memberikan hasil tentang konsep keteledanan Yesus Pertama, keteladanan Yesus sebagai pemimpin dalam prinsip (Аy. 2). Hal tersebut dinyatakan dengan cara: pertama, sehati sepikir dalam satu kasih, satu jiwa dan satu tujuan. Kedua, peduli dengan kepentingan orang lain. Kedua, keteladan

129 Pendeta GPDP Klasis Mimika, Pertama, keteladanan dalam kepribadian. Kedua, keteladanan dalam prinsip. Ketiga, keteladanan dalam pelayanan, diwawancara oleh Fransiscus Xaferius Wanggai, Sutikto, dan Roberth Ruland Marini Marini, Wawancara, 2021. 
Yesus sebagai pemimpin dalam pelayanan (ayat 3,4,8), hal tersebut ditunjukkan dengan Yesus memberi teladan merendahkan diri dengan cara: tidak menganggap kesetaraan dengan Allah sebagai milik yang harus dipertahankan (Flp. 2: 6), mengambil rupa seorang hamba (Flp. 2: 7), menjadi sama dengan manusia (Flp. 2: 7), dan telah merendahkan diri-Nya (Flp. 2: 8). Ketiga, teladan Yesus sebagai pemimpin dalam kepribadian (Ayat 6-7). Hal ini terlihat dalam pengosongan diri Yesus yang tidak sekadar berarti secara sukarela menahan diri menggunakan kemampuan dan hak istimewa ilahi-Nya, tetapi juga menerima penderitaan, kesalahpahaman, perlakuan buruk, kebencian dan kematian yang terkutuk di salib.

\section{PEMBAHASAN}

Dalam pembahasan ini akan disajikan tentang kepemimpinan rohani, pentingnya keteladanan pemimpin dan keteladanan pemimpin rohani menurut Filipi 2: 1-8. Pada pembahasan menurut Filipi 2:1-8 akan dijelaskan tentang keteladanan Yesus sebagai pemimpin rohani yang dapat diimplementasikan di kalangan gembala sidang GPDP Klasis Mimika.

\section{Kepemimpinan Rohani}

Kepemimpinan rohani yang Alkitabiah berbeda dengan kepemimpinan secara umum. Joice Meyer mengatakan, setiap orang percaya perlu menjadikan Yesus Kristus sebagai teladan dalam hidup dan kepemimpinannya. ${ }^{13}$ John Mac Arthur juga mengatakan bahwa kepemimpinan yang sejati adalah memberikan pengaruh positif bagi orang-orang yang dipimpin, bukan dengan tekanan atau

13 Joice Meyer, Pemimpin yang sedang dibentuk (Jakarta: Imanuel, 2005), 252. 
paksaan. Kepemimpinan bukanlah tentang gaya atau teknik, melainkan karakter. ${ }^{14}$ Jadi kepemimpinan rohani adalah model kepemimpinan yang mencerminkan kepemimpinan Kristus.

Pemimpin rohani perlu menjadikan dirinya sebagai panutan, pengayom, pembimbing, pembina dan pengajar bagi jemaat yang digembalakan. Meskipun pemahaman ini sangat sederhana tetapi mengandung makna tentang kepemimpinan yang Alkitabiah secara menyeluruh. ${ }^{15}$ Para pemimpin rohani menyandang tiga jabatan yang berbeda namun saling berkaitan, yaitu penatua, penilik (pengawas atau bishop) dan gembala (atau pastor). ${ }^{16}$ Dapat disimpulkan bahwa kepemimpinan dalam gereja terutama berfungsi untuk pengembalaan jemaat. Oleh karena sumber dan tujuan gereja adalah Yesus Kristus, maka arah kepemimpinan dalam gereja difokuskan pada teladan Yesus Kristus.

Pengangkatan pemimpin rohani dalam gereja berbeda mekanismenya dengan proses pengangkatan pemimpin dalam organisasi politik atau organisasi masyarakat. Ada syarat-syarat rohani yang harus terpenuhi, yang terutama adalah berkenan di hadapan Allah. Beberapa pemimpin yang dipakai Tuhan secara luar biasa seperti tercatat dalam Alkitab menunjukan dua sifat yang sangat menonjol, yaitu kerendahan hati dan merasa diri tidak layak di hadapan Tuhan dan segala sesuatu menyangkut keberhasilannya itu semata-mata berasal dari Tuhan. Tingkat ketergantungan pemimpin rohani kepada Tuhan itu amat tinggi dan sangat signifikan terhadap kinerja kepemimpinan sang pemimpin. Semakin besar

14 John MacAhartur, Kitab Kepemimpinan : 26 karakter pemimpin sejati menurut Paulus (Jakarta: BPK Gunung Mulia, 2017), ix. 21.

15 Samuel Tandiassa, Kepemimpinan Gereja Lokal (Yogyakarta: Moriel Publishing House, 2010), 11.

16 Derek Prince, Membangun Jemaat Kristus (Jakarta: Yayasan Pekabaran Injil Immanuel, 2001), 
kebutuhan pemimpin akan campur tangan Tuhan, maka semakin berhasil pula ia melakukan tugasnya.

Seorang pemimpin adalah tokoh yang menjadi panutan bagi semua orang yang dipimpinnya. Pemimpin haruslah menjadi teladan dalam seluruh aspek kehidupannya. ${ }^{17}$ Kepemimpinan Kristen adalah kepemimpinan yang memiliki tanggung jawab kepada Allah, ${ }^{18}$ mampu membuat perubahan yang lebih baik, berguna bagi semua orang dan memuliakan Allah. ${ }^{19}$ Seorang pemimpin harus tahu apa yang menjadi tanggung jawabnya serta berkomitmen untuk membuat orang yang dipimpinnya berhasil mencapai tujuan yang telah ditetapkan. ${ }^{20}$ Jadi dalam kepemimpinan Kristen yang menonjol adalah melayani.

\section{Pentingnya Keteladanan Pemimpin}

Kata keteladanan berasal dari kata teladan yang dalam Kamus Besar Bahasa Indonesia (KBBI) berarti perbuatan yang patut ditiru dan dicontoh. ${ }^{21}$ Sedangkan kata keteladanan diartikan hal-hal yang dapat ditiru atau dicontoh. ${ }^{22}$ Kata "teladan" dalam bahasa Yunani berasal dari kata (hupodeingma) yang diterjemahkan ”teladan, contoh, tiruan.” Di dalam Perjanjian Baru kata ini hanya muncul enam kali (Lih.Yoh. 13: 15; Ibr. 4: 11; 8: 5; 9: 23; Yak. 5: 10; 2Ptr. 2: 6). ${ }^{23}$

17 Ezra Tari, Ermin Alperiana Mosooli, dan Elsye Evasolina Tulaka, "Kepemimpinan Kristen Berdasarkan 1 Timotius 3: 1-7," Jurnal Teruna Bhakti 2, no. 1 (2019): 15, https://doi.org/10.47131/jtb.v2i1.22. 18 Purwanto, "Kepemimpinan Yesus Kristus sebagai Model Kepemimpinan Kristen," 131.

${ }^{19}$ Suhadi Suhadi dan Yonatan Alex Arifianto, "Pemimpin Kristen Sebagai Agen Perubahan di Era Milenial," EDULEAD: Journal of Christian Education and Leadership 1, no. 2 (2020): 129, https://doi.org/10.47530/edulead.v1i2.32.

20 Fridayana Yudiaatmaja, "Kepemimpinan: Konsep, Teori Dan Karakternya," Media Komunikasi FPIPS 12, no. 2 (2013): 29, http://dx.doi.org/10.23887/mkfis.v12i2.1681.

${ }^{21}$ Kamus Besar Bahasa Indonesia (Jakarta: Balai Pustaka, 2002), 1160.

22 Kamus Besar Bahasa Indonesia, 1160.

23 Hasan Sutanto, Perjanjian Baru Interlinear Yunani-Indonesia dan Konkordansi Perjanjian Baru II (Jakarta: Lembaga Alkitab Indonesia, 2004), 780. 
Ketaatan dan ketekunan pada Firman Tuhan menghasilkan keteladanan. Setiap orang percaya dapat menjadi teladan jika hidup dalam kebenaran dan menjadi berkat bagi sesama, bukan hanya saat dilihat orang tetapi saat tidak ada yang melihat. Itu berarti keteladanan memiliki sifat permanen dan konsisten. Jadi dapat dikatakan bahwa keteladanan sangat erat kaitannya dengan kedewasaan rohani. Orang yang dewasa rohani pastilah memiliki integritas yang baik. Surat I Timotius 4: 12b menasihatkan supaya menjadi teladan bagi orang-orang percaya, dalam perkataan, tingkah laku, kasih, kesetiaan dan dalam kesucian. Dari sini ada lima hal yang firman Tuhan ingatkan, yaitu perkataan yang bijak dan memberi semangat/dorongan, tingkah laku, respons yang positif, kasih agape, kesetiaan, komitmen, konsekuen, konsisten dan kesucian atau menjaga kekudusan. Yesus Kristus adalah teladan bagi orang percaya. Hal itu terbukti sampai Yesus mati di kayu salib demi keselamatan umat manusia (1Ptr. 2: 21). Jadi keteladanan dari Yesus Kristus yang patut ditiru, diikuti dan dicontoh, baik dalam pikiran, perkataan, perbuatan maupun seluruh hidup batiniah-Nya.

Bila kehidupan seorang pemimpin buruk maka akan memberikan contoh buruk kepada orang yang dipimpinnya. Lumintang mengatakan, masalah dunia dan gereja adalah masalah pemimpin, sedikit yang baik dan banyak yang buruk. ${ }^{24}$ Bila pemimpin memiliki nilai positif maka dapat menjadi contoh yang baik bagi orang yang dipimpinnya. Menurut Manno, suatu sikap hidup bernilai kebenaran dan kebaikan dapat diikuti atau ditiru untuk dihidupi dan diteruskan kepada generasi berikutnya adalah teladan dalam kualitas pengetahuan, keahlian dan

${ }^{24}$ Stevri Indra Lumintang, Theologia kepemimpinan Kristen. Theokrasi di tengah Sekularisasi Gereja Masa Kini (Jakarta: Institut Theologia Indonesia, 2015), 1-2. 
moral. Maka sebagai pemimpin bila berada di depan sebagai teladan, di tengah sebagai penyemangat dan di belakang sebagai pendorong mencapai tujuan. ${ }^{25}$

\section{Keteladanan Pemimpin Rohani Menurut Filipi 2: 1-8}

Surat Rasul Paulus kepada jemaat di Filipi adalah surat yang sangat pribadi, mencerminkan kedekatan antara Paulus dan jemaat di Filipi. Nada utamanya adalah sukacita, ini yang membedakan surat Filipi dari surat-surat Rasul Paulus yang lain. Perkataan sukacita, baik sebagai kata benda maupun sebagai kata kerja, terdapat 16 kali dalam surat ini. Rasul Paulus dikuatkan Tuhan sehingga dapat bersukacita walaupun menderita belenggu. Kehidupan Rasul Paulus penuh dengan sukacita dan dalam surat menasihatkan jemaat di Filipi agar bersukacita dalam Tuhan. Paulus mengirimkan nasihat ini saat dibelunggu dalam penjara dan masih menunggu keputusan perkaranya yang mungkin mendatangkan kematian. $^{26}$

Surat Filipi merupakan ungkapan syukur Paulus atas segala pemberian dan dukungan dari jemaat selama Paulus berada dalam penjara. ${ }^{27}$ Ada dua bagian yang menonjol dalam surat ini yaitu, pasal 2: 5-11 dan 3: 2-15, masing-masing menyatakan ketaatan Kristus yang luar biasa pada kehendak Allah. Paulus yang berkobar-kobar untuk mencapai tujuan Kristus yang telah memanggilnya. Bagian pertama ditulis semata-mata sebagai Kristologi, tetapi diberikan untuk melukiskan kerendahan hati yang dianjurkan Paulus pada jemaat di Filipi. $^{28}$ Keteladanan dalam konteks Filipi 2: 1-8 ditujukan kepada pribadi Yesus Kristus.

25 Daud Manno, Kompetensi Integratif Tuhan Yesus sebagai Guru (Jakarta: Yayasan Kasih Imanuel, 2018), 73.

26 J. Wesley Brill, Tafsiran Surat Filipi (Bandung: Kalam Hidup, 2003), 9.

${ }^{27}$ Kornelius A Setiawan, "RAHASIA KEKUATAN PAULUS DALAM MENGHADAPI TANTANGAN HIDUP (FILIPI 4: 10-20)," t.t.

28 Merrill C. Tenney, Survei Perjanjian Baru (Malang: Gandum Mas, 2013), 404. 
Rasul Paulus mengingatkan bahwa Yesus adalah teladan pemimpin rohani yang terbaik dan dapat diikuti oleh semua pemimpin rohani. Selama tiga setengah tahun, Yesus memuridkan dan memberi pengaruh yang sangat besar. Sebagai pemimpin, Yesus mampu menjalankan visi misi serta tujuan-Nya selama berada di bumi. ${ }^{29}$ Menurut surat Filipi 2: 1-8, Yesus Kristus dapat diteladani dari aspek prinsip, pelayanan, dan kepribadian.

\section{Keteladanan Yesus Sebagai Pemimpin Dalam Prinsip (Ay. 2)}

Paulus mengajarkan bahwa perlunya seorang pemimpin meneladani Yesus dalam memegang prinsip pelayanan. Hal utama yang Paulus tegaskan pada bagian ini adalah kesatuan dalam Kristus. Maksudnya ialah sehati sepikir dalam satu kasih, satu jiwa dan satu tujuan. Untuk mencegah terjadinya perselisihan hingga perpecahan maka harus memegang prinsip kesatuan dalam Kristus. Paulus menasehatkan jemaat untuk mencapai sukacita yang sempurna yaitu dengan cara sehati sepikir dalam satu kasih, satu jiwa dan satu tujuan. ${ }^{30}$ Jika seseorang ada dalam Kristus maka akan sehati sepikir dalam satu kasih, satu jiwa dan satu tujuan dengan semua orang yang juga ada di dalam Kristus.

Pengajaran Paulus merupakan hal yang sangat penting, bukan hanya bagi jemaat Filipi tetapi juga untuk setiap orang percaya. Paulus menasehatkan agar jemaat tidak mencari kepentingan sendiri atau puji-pujian yang sia-sia (ay. 3) sebagaimana Yesus memberikan teladan rela meninggalkan kemuliaan-Nya menjadi sama dengan manusia dan rela mati demi umat manusia. Jadi teladan Yesus dalam prinsip yaitu hidup dalam kesatuan dengan cara: pertama, sehati

${ }^{29}$ Nico J.J. Koroh, Manajemen Yang Melayani: Sebuah Tinjauan Konsep Manajemen Melalui Pendekatan Alkitabiah (Jakarta: Mitra Mark, 2003), 124.

30 Marsi Bombongan Rantesalu, "EKSPOSISI FILIPI 2: 1-11," 2019. 
sepikir dalam satu kasih, satu jiwa dan satu tujuan. Kedua, peduli dengan kepentingan orang lain.

\section{Keteladan Yesus Sebagai Pemimpin Dalam Pelayanan (ayat 3,4,8)}

Keteladanan Yesus dalam pelayanan terlihat dalam tiga hal yaitu: rendah hati (ayat 3), tidak mementingkan diri sendiri (ayat 4) dan taat sampai mati (ayat 8). Dalam Bahasa Yunani kata rendah hati adalah $\tau \alpha \pi \varepsilon$ vo (tapeinophrosune). Paulus menjelaskan bahwa Yesus memberi teladan merendahkan diri dengan cara: tidak menganggap kesetaraan dengan Allah sebagai milik yang harus dipertahankan (Flp. 2: 6), mengambil rupa seorang hamba (Flp. 2: 7), menjadi sama dengan manusia (Flp. 2: 7), dan telah merendahkan diri-Nya (Flp. 2: 8).

Yesus tidak menganggap kesetaraan dengan Allah sebagai milik yang harus dipertahankan, ini berarti Yesus melakukan bukan karena terpaksa atau pura-pura. Yesus mengambil rupa seorang hamba, Yesus mengesampingkan kemuliaan, kedudukan, kekayaan, segala hak sorgawi dan penggunaan sifat-sifat ilahi-Nya. Yesus menjadi sama dengan manusia atas kehendak-Nya sendiri, membuat diri-Nya sama dengan manusia dalam wujud nyata. Paulus menasehatkan kerendahan hati yang sejati bukan hanya nampak secara lahiriah tetapi sikap batin. Jadi setiap orang percaya perlu memiliki kerendahan hati seperti Kristus, secara khusus para pemimpin yang terpanggil untuk melayani, tidak mementingkan diri sendiri dan berbuat baik kepada orang yang dipimpinnya. ${ }^{31}$

31 Julian Frank Rouw dan Sugiono Sugiono, "Syair Kristologi Tentang Ke-Allah-An Yesus Dalam Filipi 2: 6-11," Veritas Lux Mea (Jurnal Teologi dan Pendidikan Kristen) 1, no. 2 (2019): 140, https://jurnal.sttkn.ac.id/index.php/Veritas/article/view/46/pdf. 
Yesus juga tidak mementingkan diri sendiri. Jemaat Filipi perlu memiliki gaya hidup yang berbeda dengan mereka yang di luar Kristus. Sikap mementingkan diri sendiri bukanlah teladan dari Yesus, sebaliknya dalam hidup setiap orang percaya perlu menaruh pikiran dan perasaan yang terdapat juga dalam Kristus Yesus (ay. 5). Kristus mengosongkan diri adalah bukti nyata bahwa Yesus tidak mementingkan diri sendiri. Hal ini dapat diteladani oleh para pengikut-Nya sehingga hidup menjadi berkat dan memuliakan Allah. Penyerahan diri Yesus sangat mengagumkan. Yesus mengungkapkan diri sebagai anak manusia menunjukkan keadaan yang terendah sebagai seorang hamba. ${ }^{32}$ Semakin dalam Yesus merendahkan diri semakin tinggi Ia diangkat ke dalam kemuliaan surgawi.

Selanjutnya, Yesus taat sampai mati dalam bahasa Yunani dituliskan

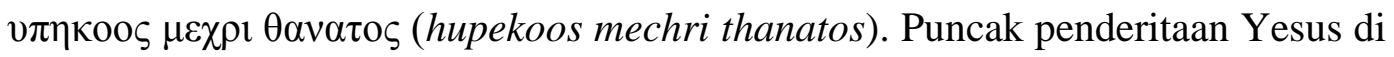
kayu salib merupakan bukti kasih Allah bagi isi dunia. ${ }^{33}$ Kematian-Nya adalah sebuah penebusan dosa. ${ }^{34}$ Walaupun Yesus tetap benar-benar ilahi, Kristus mengambil sifat manusia dengan segala pencobaan, kehinaan dan kelemahannya, namun tanpa dosa (Flp. 2: 7-8; Ibr 4: 15). Piper menuliskan bahwa pengorbanan Yesus di kayu salib adalah kemuliaan anugerah Allah. ${ }^{35}$ Jadi Kristus mengambil rupa seorang hamba dan menjadi sama dengan manusia, turut merasakan seluruh kelemahan manusia, kecuali dalam dosa.

\section{Teladan Yesus Sebagai Pemimpin Dalam Kepribadian (Ayat 6-7)}

32 Oscar Cullman, Christology of the New Testament (Philadelphia: Westminster Press, 1963), 60.

33 James C. Wilhoit Leland Ryken dan Tremper Longman III, Kamus Gambaran Alkitab (Surabaya: Momentum, 2011), 241.

34 George Eldon Ladd, Teologi Perjanjian Baru Jilid 1 (Bandung: Kalam Hidup, 2002), 248.

35 John Piper, Penderitaan dan Kedaulatan Allah (Surabaya: Momentum, 2012), 94-96. 
Keteladanan dari Yesus sesungguhnya dapat dilihat dari seluruh kehidupan Yesus secara utuh, baik dari sisi keilahian dan kemanusiaan Yesus yang sempurna. Louis E. Lebar mengatakan, sebagai guru Yesus berasal dari Allah. ${ }^{36}$ Yesus adalah Sang Firman yang menjadi manusia, berasal dari Allah dan memiliki sifat ilahi. Namun Yesus mengalami inkarnasi menjadi manusia, untuk melaksanakan tugas sebagai Mesias. Yesus dalam rupa Allah mengambil rupa manusia, mengalami pengosongan diri artinya tidak menggunakan kapasitasnya sebagai Allah, namun rela menghambakan diri menjadi pelayan. Inilah sifat atau karakter Yesus sebagai pemimpin dalam sejarah dunia.

Yesus telah mengosongkan diri mengambil rupa seorang hamba, dan menjadi sama dengan manusia. Dalam hal ini Yesus menjadi teladan bagaimana dari keilahian-Nya yang penuh kuasa, kemuliaan dan kemahahadiran, tetapi mengambil tempat sebagai manusia, untuk dapat menolong manusia yang berdosa. Pada hakikatnya Yesus Kristus selalu adalah Allah (Yoh. 1: 1; Yoh. 8: 58; 17: 24; Kol. 1: 15-17), Pengosongan diri Yesus ini tidak sekadar berarti secara sukarela menahan diri untuk menggunakan kemampuan dan hak istimewa ilahiNya, tetapi juga menerima penderitaan, kesalahpahaman, perlakuan buruk, kebencian dan kematian yang terkutuk di salib.

Yesus pada hakikatnya adalah Allah. Itu berarti Ia memiliki sifat-sifat ilahi. Kesetaraan dengan Allah itu tidak dianggap sebagai "rampasan" (yang perlu dipertahankan, atau perlu direbut). Kesetaraan itu bukan mengenai zat atau hakikat sebab kalimat "dalam rupa Allah" berarti tidak dapat ditinggalkan, tetapi mengenai kesetaraan kehormatan, hakikat yang menyatakan dirinya di luar dan

${ }^{36}$ Louis E. Lebar, Proses Belajar Mengajar Kristen \& Kurikulum yang Alkitabiah (Malang: Gandum Mas, 2006), 73-75. 
diakui. Kristus dapat mempertahankan dan menuntut kehormatan itu juga dalam keadaan-Nya sebagai manusia. Yesus sebagai teladan pemimpin memiliki pikiran yang sehat dan perasaan yang penuh dengan belaskasihan. Keberhasilan pemimpin rohani tidak bergantung kemampuan, kharisma atau pengalaman tetapi tergantung pada kehidupan batiniah. ${ }^{37}$

\section{Implementasi Keteladanan Pemimpin Rohani}

Berikut adalah deskripsi singkat tentang GPDP Tanah Papua - Klasis Mimika. Pada tahun 2001, sejalan dengan perubahan nama Irian Jaya menjadi Papua oleh pemerintah, maka Gereja Pentakosta di Irian Jaya melalui Sidang Istimewa pada tanggal 5 Juni 2001, bertempat di Gedung Museum Budaya Provinsi Papua - Jayapura, mengambil keputusan menyesuaikan namanya menjadi "Gereja Pentakosta Di Papua" disingkat GPDP dengan jumlah Gembala Sidang saat ini 254 dan jumlah klasis yang tersebar di seluruh Indonesia berjumlah 37 Klasis. Klasis Mimika berdiri tahun 1997, dirintis oleh Pdt. Yustinus Tarasen, Pdt. Piethein Blesskadit dan beberapa hamba Tuhan lainnya. Mengawali pelayanan dengan membuka tiga sidang jemaat hingga di tahun 2020 sudah berjumlah sembilan sidang jemaat. Berdasarkan hasil observasi dan wawancara terstruktur tentang keteladan pemimpin rohani menurut Filipi 2: 1-8 pada sembilan partisipan maka diperoleh hasil sebagai berikut:

\section{Keteladanan dalam Prinsip}

Para hamba Tuhan GPDP Klasis Mimika menyukai keteladanan pemimpin rohani dalam memegang prinsip. Semua menjawab dengan baik sekali bahkan nampaknya para hamba Tuhan ini cukup memahami konsep keteladanan

37 Peter Scazzero, Gereja yang Sehat Secara Emosional: Sebuah Strategi untuk Pemuridan yang Benar-benar Mengubah Kehidupan (Batam: Gospel Press, 2005), 27. 
dari ajaran Paulus dalam surat Filipi 2 tersebut. Jawaban dari para partisipan mengambarkan pemahaman dan keinginan mereka menjadi seorang pemimpin rohani teladan dalam memegang prinsip. Bila para gembala ini konsisten pada apa yang mereka inginkan dengan apa yang dilakukan adalah suatu hal yang sangat baik. Jadi dalam hal ini mereka memiliki pemahaman yang cukup dari Alkitab mengenai apa yang mereka inginkan dari seorang pemimpin. Kunci keberhasilan pemimpin rohani adalah keteladanan. Mereka sedang mengarahkan diri kepada satu tujuan bersama dalam panggilan Kristus, melayani dengan dasar satu kasih, satu jiwa, melayani sehati sepikir, dengan mengutamakan kepentingan orang lain.

\section{Keteladanan dalam Pelayanan}

Para Gembala sidang GPDP klasis Mimika memiliki penilaian dan pemahaman bahwa untuk keteladanan pemimpn rohani dalam pelayanan diantara mereka harus ditingkatkan dalam hal kerja sama, saling menjaga, saling hormat menghormati, saling mendukung satu sama lain, membantu yang sedang kesusahan, mempererat persaudaraan dan kekeluargaan di antara saudara seiman dan rekan pelayan Kristus. Berarti sesama hamba Tuhan ini memahami apa yang harus mereka perjuangkan ke depan dalam pelayanan sebagai pemimpin teladan. Jika ada hal yang masih kurang dalam kepemimpinan mereka saling menasihati, terus berada dalam persekutun Roh, kasih mesra, saling menghibur dalam kasih, adanya belas kasihan dengan cara tolong-menolong di antara mereka, tidak egois, tidak hanya memikirkan kepentingkan diri sendiri, melayani dengan rendah hati satu dengan yang lainnya, melayani sebagai hamba tidak menganggap diri sebagai 
tuan atas yang lain, melayani dengan ketaatan kepada Tuhan dan organisasi sampai akhir hidup.

\section{Keteladanan dalam Kepribadian}

Para gembala sidang GPDP Klasis Mimika, menyadari bahwa di kalangan mereka juga memiliki faktor negatif yang tidak dapat dijadikan teladan. Jawaban mereka sangat jelas, dan tegas; ada yang suka bertengkar, iri hati satu dengan yang lain saling menjatuhkan, persaingan yang tidak sehat dalam pelayanan, terlalu banyak bermain, tidak saling mendukung, tidak menghargai satu sama lain, merasa iri melihat keberhasilan orang lain, banyak yang saling menjatuhkan, lebih mementingkan diri sendiri, tidak taat kepada firman Tuhan, kawin cerai, banyak bercanda yang semestinya tidak layak dilakukan, kurang peduli dengan program kerja klasis atau program kerja sinode, suka menceritakan kejelekan orang lain sesama hamba Tuhan, suka marah-marah yang tidak jelas, menanggapi sesuatu dengan emosi, tidak mau menerima usulan orang lain, berselingkuh. Hal-hal ini sangat memprihatinkan terjadi di kalangan hamba Tuhan yang melayani pekerjaan Tuhan. Hal ini perlu dilakukan pemulihan secara pribadi dan bagi semua. Dalam hal ini terjadi ketimpangan bahwa antara pengetahuan dan cara hidup sebagai pemimin rohani tidak berjalan sama, apa yang diketahui dengan apa yang dilakukan terjadi distorsi. Inilah yang disebut tidak dapat menjadi teladan, karena keteladanan adalah melakukan apa yang diajarkan dan mengajarkan apa yang dilakukan.

Ada beberapa penyebab sehingga tidak dapat menjadi teladan, yaitu belum bertobat sungguh-sungguh, belum dipenuhi dan dipimpin oleh Roh kudus, belum memahami status dan jati diri sebagai gembala, belum sungguh-sungguh ada 
dalam Tuhan dan sebaliknya Firman Tuhan tidak ada dalam dirinya, belum melakukan Firman Tuhan dengan baik dan benar, tidak mau belajar, tidak mau merendahkan diri di hadapan Tuhan, kesombongan, SDM yang minim biasa jadi karena memang pendidikan terlalu rendah. Banyak yang hanya lulusan SMP dan sebagian kecil lulusan SMA.

Beberapa hal yang sulit diubah yaitu ditemukan para gembala melihat hal negatif di kalangan sesama pemimpin jemaat. Di antaranya yaitu: tidak disiplin waktu pada rapat rapat dan ibadah ibadah; tidak setia dan taat menyetor persepuluhan ke sinode, emosional, tidak mau melihat keadaan sekitar, kurang setia, suka berbohong, suka yang muluk-muluk, kesombongan rohani, meresa lebih banyak tahu. Bagaimana pun hal yang telah disebutkan di atas memang benar adanya, memperlihatkan hal-hal yang bertentangan dengan Firman Tuhan, tetapi hal ini penting untuk ditangani bersama secara organisasi dan secara perseorangan di hadapan Tuhan. Karena para pemimpin jemaat adalah alat Tuhan melayani kerohanian jemaat dan bertugas menginjili dunia menjadi murid Krisus. Bila pemimpin jemaat sebagai ujung tombak misi penginjilan dan pendidikan dan pengembalaan memiliki kompetensi buruk dalam pelayanan dan kepribadiannya, serta tidak memegang prinsip pelayanan, maka tidak dapat berhasil. Pelayanan hanya secara rutinitas tanpa visi misi dan tujuan jelas sebagai pelaksana amanat agung Yesus Kristus.

Berdasarkan hasil wawancara di atas, maka beberapa rekomendasi untuk gembala sidang GPDP Klasis Mimika Papua, yaitu: pertama, bahwa diperlukan keteladanan dalam melayani Tuhan dan sesama. Seorang pemimpin perlu memiliki kompetensi kepribadian, profesionalisme, kompetensi sosial, dan 
kompetensi spiritualitas yang baik. Ada banyak aspek yang menjadi penyebab, sehingga gembala sidang tidak dapat menjadi teladan yang baik. Itu berarti perlu pembenahan, menghadapi masa pelayanan masa depan. Kedua, untuk meningkatkan pola hidup teladan sebagai pemimpin jemaat, maka para gembala sidang perlu: Roh Kudus dalam kehidupannya sebagai Pemimpin, merendahkan diri di hadapan Tuhan, belajar pada Yesus Kristus melalui firman-Nya, memikul salib setiap hari, berdoa, berpuasa, belajar dari para pemimpin gereja yang memiliki keteladanan hidup yang baik. Ketiga, untuk meningkatkan kompetensi, para gembala dapat mengikuti pendidikan teologia dan sinode dapat menjadi sponsor sampai para gembala menyelesaiakan pendidikannya.

\section{KESIMPULAN}

Kepemimpinan sangat dipengaruhi oleh pemimpin. Seorang pemimpin dapat memengaruhi tindakan atau perbuatan orang lain, juga dapat memengaruhi perubahan karakter orang-orang yang dipimpinnya. Dalam kepemimpinan Kristen, gembala sebagai pemimpin jemaat lokal dapat memengaruhi orang yang dipimpinnya. Surat Filipi 2:1-8 adalah tulisan Paulus yang mengajarkan tentang keteladanan Yesus Kristus sebagai pemimpin rohani, yang dapat dilihat dari prinsip, pelayanan dan kepribadian. Berdasarkan hasil wawancara dapat disimpulkan bahwa sembilan gembala GPDP Klasis Mimika Papua sebagai partisipan dalam penelitian ini dapat memahami keteladan gembala sidang sebagai seorang pemimpin rohani. Mereka megimplementasikannya dalam memegang prinsip hubungannya dengan sesama, dalam pelayanan dan kepribadian yang tujuannya untuk melaksanakan amanat agung Yesus Kristus. 


\section{DAFTAR PUSTAKA}

9 Pendeta GPDP Klasis Mimika. Pertama, keteladanan dalam kepribadian. Kedua, keteladanan dalam prinsip. Ketiga, keteladanan dalam pelayanan. Diwawancara oleh Fransiscus Xaferius Wanggai, Sutikto, dan Roberth Ruland Marini Marini. Wawancara, 2021.

B, Yosafat. Integritas Pemimpin Pastoral. Yogyakarta: ANDI, 2010.

Brill, J. Wesley. Tafsiran Surat Filipi. Bandung: Kalam Hidup, 2003.

Cullman, Oscar. Christology of the New Testament. Philadelphia: Westminster Press, 1963.

Eims, Leroy. 12 ciri kepemimpinan yang efektif. Bandung: Kalam Hidup, 2003.

Kamus Besar Bahasa Indonesia. Jakarta: Balai Pustaka, 2002.

Katarina, K, dan I Putu Ayub Darmawan. "Alkitab dalam Formasi Rohani pada Era Reformasi Gereja dan Implikasi bagi Gereja Pada Masa Kini." EPIGRAPHE: Jurnal Teologi dan Pelayanan Kristiani 3, no. 2 (18 Desember 2019): 81. https://doi.org/10.33991/epigraphe.v3i2.85.

Ketua Sinode. Kondisi Jemaat dan Kepemimpinan Gembala Sidang di GPDP Klasis Mimika, Papua. Diwawancara oleh Fransiscus Xaferius Wanggai, Sutikto, dan Roberth Ruland Marini Marini. Wawancara, 2021.

Koroh, Nico J.J. Manajemen Yang Melayani: Sebuah Tinjauan Konsep Manajemen Melalui Pendekatan Alkitabiah. Jakarta: Mitra Mark, 2003.

Ladd, George Eldon. Teologi Perjanjian Baru Jilid 1. Bandung: Kalam Hidup, 2002.

Lebar, Louis E. Proses Belajar Mengajar Kristen \& Kurikulum yang Alkitabiah. Malang: Gandum Mas, 2006.

Leland Ryken, James C. Wilhoit, dan Tremper Longman III. Kamus Gambaran Alkitab. Surabaya: Momentum, 2011.

Lumintang, Stevri Indra. Theologia kepemimpinan Kristen. Theokrasi di tengah Sekularisasi Gereja Masa Kini. Jakarta: Institut Theologia Indonesia, 2015.

MacAhartur, John. Kitab Kepemimpinan: 26 karakter pemimpin sejati menurut Paulus. Jakarta: BPK Gunung Mulia, 2017.

Manno, Daud. Kompetensi Integratif Tuhan Yesus sebagai Guru. Jakarta: Yayasan Kasih Imanuel, 2018. 
Maxwell, John. C. Mengembangkan kepemimpinan di dalam diri anda. Tangerang: Binarupa Aksara, 2010.

Meyer, Joice. Pemimpin yang sedang dibentuk. Jakarta: Imanuel, 2005.

Panekenan, Martje. "Pola Kepemimpinan Kristen Menurut Injil Yohanes 13: 120." Educatio Christi 1, no. 1 (2020): 41-52. https://ejournal.teologiukit.ac.id/index.php/educatio-christi/article/view/9/6.

Panjaitan, Firman. "Kepemimpinan Yesus Kristus sebagai Model Dasar Kepemimpinan Kristen Berdasarkan Matius 20: 20-28." KINAA: Jurnal Kepemimpinan Kristen dan Pemberdayaan Jemaat 1, no. 2 (2020): 91110. https://doi.org/10.34307/kinaa.v1i2.14.

Piper, John. Penderitaan dan Kedaulatan Allah. Surabaya: Momentum, 2012.

Prince, Derek. Membangun Jemaat Kristus. Jakarta: Yayasan Pekabaran Injil Immanuel, 2001.

Purwanto, Agus. "Kepemimpinan Yesus Kristus sebagai Model Kepemimpinan Kristen." Mathetes: Jurnal Teologi dan Pendidikan Kristen 1, no. 2 (2020): 131-46. https://sttbethelsamarinda.ac.id/ejournal/index.php/mathetes/article/view/17.

Rantesalu, Marsi Bombongan. "EKSPOSISI FILIPI 2: 1-11,” 2019.

Rouw, Julian Frank, dan Sugiono Sugiono. "Syair Kristologi Tentang Ke-AllahAn Yesus Dalam Filipi 2: 6-11." Veritas Lux Mea (Jurnal Teologi dan Pendidikan Kristen) 1, no. 2 (2019): 140-54. https://jurnal.sttkn.ac.id/index.php/Veritas/article/view/46/pdf.

Samarenna, Desti, dan Harls Evan R Siahaan. "Memahami Dan Menerapkan Prinsip Kepemimpinan Orang Muda Menurut 1 Timotius 4: 12 Bagi Mahasiswa Teologi." BIA': Jurnal Teologi dan Pendidikan Kristen Kontekstual 2, no. 1 (2019): 1-13. https://doi.org/10.34307/b.v2i1.60.

Scazzero, Peter. Gereja yang Sehat Secara Emosional: Sebuah Strategi untuk Pemuridan yang Benar-benar Mengubah Kehidupan. Batam: Gospel Press, 2005.

Setiawan, Kornelius A. "RAHASIA KEKUATAN PAULUS DALAM MENGHADAPI TANTANGAN HIDUP (FILIPI 4: 10-20)," t.t.

Suhadi, Suhadi, dan Yonatan Alex Arifianto. "Pemimpin Kristen Sebagai Agen Perubahan di Era Milenial." EDULEAD: Journal of Christian Education $\begin{array}{lllll}\text { and Leadership 1, no. } 2 & \text { (2020): } & \text { 129-47. }\end{array}$ https://doi.org/10.47530/edulead.v1i2.32.

Sutanto, Hasan. Perjanjian Baru Interlinear Yunani-Indonesia dan Konkordansi Perjanjian Baru II. Jakarta: Lembaga Alkitab Indonesia, 2004. 
Tandiassa, Samuel. Kepemimpinan Gereja Lokal. Yogyakarta: Moriel Publishing House, 2010.

Tari, Ezra, Ermin Alperiana Mosooli, dan Elsye Evasolina Tulaka. "Kepemimpinan Kristen Berdasarkan 1 Timotius 3: 1-7." Jurnal Teruna Bhakti 2, no. 1 (2019): 15-21. https://doi.org/10.47131/jtb.v2i1.22.

Tarigan, Sayang, dan Yanto Paulus Hermanto. "Kepemimpinan Tuhan Yesus di Masa Krisis Sebagai Model Kepemimpinan Kristen Saat Ini." HARVESTER: Jurnal Teologi dan Kepemimpinan Kristen 6, no. 1 (2021): 38-54. https://doi.org/10.52104/harvester.v6i1.54.

Tenney, Merrill C. Survei Perjanjian Baru. Malang: Gandum Mas, 2013.

Utomo, Bimo Setyo. "Karakteristik Kepemimpinan Hamba Yesus Kristus Menurut Filipi 2: 5-8." DIEGESIS: Jurnal Teologi Kharismatika 3, no. 2 (2020): 107-19. https://doi.org/10.53547/diegesis.v3i2.78.

Yudiaatmaja, Fridayana. "Kepemimpinan: Konsep, Teori Dan Karakternya." Media Komunikasi FPIPS 12, no. 2 (2013): 29-38. http://dx.doi.org/10.23887/mkfis.v12i2.1681. 